DOI: $10.17957 / \mathrm{IJAB} / 15.1776$

http://www.fspublishers.org

\title{
Characterization and Inhibitory Effects of an Antifungal Protein from the Bacillus cereus Strain YN917
}

\author{
Hu Zhou ${ }^{1,2,3}$, Huajun $\mathrm{Zhu}^{1,2,3}$, Ling $\mathrm{Hu}^{1}$, Xiyue $\mathrm{Yu}^{1}$, Zuohua Ren ${ }^{1,2,3}$ and Erming Liu ${ }^{1,2,3 *}$ \\ ${ }^{1}$ College of Plant Protection, Hunan Agricultural University, Changsha, Hunan Province, P. R. China \\ ${ }^{2}$ Hunan Provincial Key Laboratory for Biology and Control of Plant Diseases and Plant Pests, Changsha, Hunan Province, \\ P. R. China \\ ${ }^{3}$ Southern Regional Collaborative Innovation Center for Grain and Oil Crops in China, Changsha, Hunan Province, P. R. \\ China
}

*For correspondence: ermingliu@163.com

Received 19 October 2020; Accepted 19 February 2021; Published 16 April 2021

\begin{abstract}
In this research, a type of antifungal protein derived from the Bacillus cereus strain YN917, was precipitated by ammonium sulfate after fermentation. We investigated the antifungal effects and antifungal mechanism of the protein as well as its stability under different stress conditions such as the variation of temperature, $\mathrm{pH}$ value, exposure to ultraviolet radiation and proteases. Furthermore, the in vitro needle inoculation method was carried out to explore the antagonistic effects of $40 \%$ isoprothiolane Wettable powder (WP), 20\% tricyclazole WP and the YN917 antifungal protein against the rice blast pathogen, Magnaporthe oryzae. Results showed that 20\% tricyclazole WP and $40 \%$ isoprothiolane EC treatments had significant antagonistic effects on rice blast, and that the YN917 protein also had a dual inhibitory effect on mycelium growth and conidiospore germination in M. oryzae, which can cause this mycelium to swell and twist. The YN917 protein had a broad inhibitory spectrum with different effects on 15 plant- associated pathogenic fungi and oomycetes, such as Botrytis cinerea, Bipolaris maydis and $M$. oryzae. In addition, the physical and chemical properties of this antifungal protein were relatively stable and have potential for application in the biocontrol of fungal pathogens in plants. Overall, the results revealed that this protein has a wide tolerance to different temperatures, $\mathrm{pH}$ values, exposures to ultraviolet radiation and proteases, which is required for it to function as a bio-control agent against rice blast under a wide range of environmental conditions. (C) 2021 Friends Science Publishers
\end{abstract}

Keywords: Antifungal protein; Bacillus cereus; Biocontrol; Hyphal growth; Magnaporthe oryzae

\section{Introduction}

Rice blast is a fungal disease that seriously affects rice yield and quality and is caused by the pathogen known as Magnaporthe oryzae. The annual worldwide loss of rice yield accounts for about $10-30 \%$ of the total yield and has caused extreme losses to the agricultural industry sector (He et al. 2019). Extensive research on methods to prevent and control rice blast has been undertaken worldwide. At present, rice blast is mainly controlled by resistant varieties and by both chemical and biological control resources (Kusajima et al. 2018; Kong et al. 2018; Kimura and Fukuchi 2018; Javaid et al. 2019). Among these, the application of chemical fungicides is effective, but it presents challenging downsides, such as the presence of fungicide residues in rice grains, increased production costs and a harmful impact on human health and the environment (Liu et al. 2017; Wu et al. 2018). Moreover, plant pathogens can become resistant to fungicides, and cause biological imbalances and environmental contamination (Stadnik and Borzecki 2009). In order to maintain the common goal of sustainable agriculture development, the production and utilization of bio-fungicides to control rice blast have seen a rapid growth in recent years. A variety of microorganisms such as bacteria, fungi, oomycetes and their related metabolites can be developed as biological control agents to replace chemical fungicides (Al-Reza et al. 2010; Hammami et al. 2011; Ali et al. 2020; Shoaib et al. 2020; Sharf et al. 2021). At present, many bio-control microorganisms exist, such as Bacillus spp., Pseudomonadaceae spp., Agrobacterium radiobact, Actinomycesbovis spp., Coniothyrium, Micromonospora spp., Achromobacter spp., Serratia marcescens, Bipolaris spp. (Johansson et al. 2014), which can be used to control rice blast.

Ongena and Jacques (2008) reported that Bacillus spp. could be one of the major sources of potential microbial fungicides due to their valuable characteristics. They can

To cite this paper: Zhou H, H Zhu, L Hu, X Yu, Z Ren, E Liu (2021). Characterization and inhibitory effects of an antifungal protein from the Bacillus cereus strain YN917. Intl J Agric Biol 25:1153-1160 
prevent and control several plant diseases, including rice blast. A variety of Bacillus strains are currently commercialized as bio-fungicides (Bodhankar et al. 2017; Etesami et al. 2019); for example, the American AgraQuest Company developed a bactericide preparation Serenade ${ }^{\mathrm{TM}}$ with B. subtilis strain QST 713 and Souata AS with B. pumilus strain QST 2808 (Dorighello et al. 2015). Bayer, a German crop science company developed Kodiak ${ }^{\circledR}$ Concentrate with a B. subtilis strain (Dowd et al. 1998). China also has developed microbial preparations, Yunnan Xingyao Biological Products Factory, Yunnan Agricultural University and China Agricultural University cooperative developed the microbial fungicide Baikang with B. subtilis strain B908 (Ryder et al. 2005) and Nanjing Agricultural University made a live bactericide preparation named Maifengning with B. subtilis strain B3 (Zhang et al. 1994). Bacillus spp. is the main bio-control agent used against rice blast. By June 2019, there were 19 products derived from Bacillus spp. registered in China (including $B$. subtilis, B. cereus, B. amyloliquefaciens), 15 of which ( $80 \%$ of the total) were derived from $B$. subtilis.

In the early stage, a bio-control strain of B. cereus, named YN917, was successfully isolated from a healthy rice leaf sample of the susceptible rice cultivar 'Xiangzaoxian No. 24', which had a significant inhibitory effect on $M$. oryzae. Therefore, considering the priority of searching for natural alternatives to chemical fungicides, the research aim was to separate a type of antifungal protein from the $B$. cereus YN917 strain, and investigate its antifungal effects; specifically, we used ammonium sulfate for the precipitation of the YN917 antifungal protein. The stability, inhibition spectrum, characteristics and antifungal mechanism of this protein were investigated to offer a theoretical basis for the biological control of rice blast and development of natural bio-fungicides.

\section{Materials and Methods}

\section{Experimental material}

The $B$. cereus strain YN917 (16S rRNA GenBank: MT990515.1) used in this study was isolated from a healthy rice leaf sample of the susceptible rice cultivar 'Xiangzaoxian No 24' and stored in the Laboratory of Plant Pathogenic Microorganisms and Rice Diseases, Hunan Agricultural University, Changsha, China. Unless otherwise specified, the strain was grown on Luria-Bertani medium (10.0 $\mathrm{g} \mathrm{L}^{-1}$ tryptone, $5.0 \mathrm{~g} \mathrm{~L}^{-1}$ yeast extract, $10.0 \mathrm{~g} \mathrm{~L}^{-1} \mathrm{NaCl}$ and $\mathrm{pH} 7.0$ ) at $28^{\circ} \mathrm{C}$. Stock cultures were maintained in $50 \%$ $(v / v)$ glycerol at $-80^{\circ} \mathrm{C}$ to provide a stable inoculum during the study period.

The tested fungus was rice blast (M. oryzae) and other phytopathogenic fungi such as Botrytis cinerea, Bipolaris maydis, Ustilaginoidea virens, Fusarium graminearum, Phytophthora parasitica var. nicotianae, Alternaria solani, Rhizoctonia solan, Verticillium dahliae, A. alternata,
Diaporthe citri, F. oxysporum, Colletotrichum gloeosporioides and Sclerotinia sclerotiorum.

Indica rice 'Yuzhenxiang' and 'Xiangwanxian No.12' (Gold Nongfeng Seed Industry Technology Co., Ltd., China), and hybrid rice 'YLiangyou 1998' (Hunan hope Seed Technology Co., Ltd., China) were used as the test rice varieties. The tested fungicides were $40 \%$ isoprothiolane EC' (500 times dilution), (Jiangsu Jiangnan agrochemical Co., Ltd., China), and ' $20 \%$ tricyclazole WP' (750 times dilution), (Jiangsu Changqing agrochemical Co., Ltd., China).

\section{Preparation of antifungal proteins}

The antifungal proteins of strain YN917 were extracted using the ammonium sulfate fractional salting out method. After fermentation, the culture broth of the B. cereus strain YN917 was centrifuged at $10000 \mathrm{r} \mathrm{min}^{-1}$ for $15 \mathrm{~min}$ at $4^{\circ} \mathrm{C}$ to remove bacterial cells, and then the cell-free supernatant was adjusted to $20,30,40,50,60,70,80$ and $90 \%$, in this order, with solid ammonium sulfate under ice bath conditions. It was then stored at $4{ }^{\circ} \mathrm{C}$ for $48 \mathrm{~h}$. The precipitate was obtained by centrifugation at $10000 \mathrm{rmin}^{-1}$ for $15 \mathrm{~min}$ at $4^{\circ} \mathrm{C}$ and it was completely dissolved in phosphate buffered saline (PBS; pH 7.4). Subsequently, the precipitation was dialyzed against the same buffer for $2 \mathrm{~d}$, ammonium sulfate was removed, and the antifungal activity test was then assayed. The crude extract was filtered through a $0.22 \mu \mathrm{m}$ bacterial filter and stored at $-20^{\circ} \mathrm{C}$ until use. Each sample was examined to determine the strongest antifungal activity, which had the optimum ammonium sulfate saturation required to prepare the antifungal protein. The experiment was repeated three times.

\section{Antifungal activity assays}

The $M$. oryzae samples were placed in the center of a potato dextrose agar medium firstly, which was then cut through with a cork borer to form a hole of $6 \mathrm{~mm}$ in diameter at the edge, $25 \mathrm{~mm}$ away from the plate center. The treated protein was prepared and $40 \mu \mathrm{L}$ of respective treatments were added to each hole. Distilled water was used as the negative control. Each treatment was replicated three times. The dishes were incubated at $28^{\circ} \mathrm{C}$ until mycelial growth was reached in more than $3 / 4$ of the culture dish, the colony diameter was measured and the inhibition rate of the antifungal YN917 protein on the growth of pathogens was calculated.

\section{Determination of the antifungal spectrum}

The dual culture method was used in this study to determine the inhibition of the YN917 antifungal protein on 15 plant pathogenic fungi and oomycetes: $M$. oryzae, two $B$. cinereal strains, $B$. maydis, $U$. virens, $F$. graminearum, $P$. parasitica var. nicotianae, $A$. solani, $R$. solan, $V$. dahliae, A. alternata, $D$. citri, F. oxysporum, C. gloeosporioides, S. sclerotiorum. The experiment was carried out as described in Arpita et al. 
(2019)

\section{Assessment of stability}

High temperature tolerance: To study the thermostability of the YN917 antifungal protein, equal sample volumes were placed at $-20^{\circ} \mathrm{C}, 4^{\circ} \mathrm{C}, 20^{\circ} \mathrm{C}, 30^{\circ} \mathrm{C}, 40^{\circ} \mathrm{C}, 50^{\circ} \mathrm{C}, 60^{\circ} \mathrm{C}$, $70^{\circ} \mathrm{C}, 80^{\circ} \mathrm{C}, 90^{\circ} \mathrm{C}, 100^{\circ} \mathrm{C}$ and $121^{\circ} \mathrm{C}$, for $30 \mathrm{~min}$ and then they were quickly cooled down to room temperature on ice. pH tolerance: The $\mathrm{pH}$ values of equal sample volumes (1 $\mathrm{mL}$ ) were adjusted to 3.0, 4.0, 5.0, 6.0, 7.0, 8.0, 9.0, 10.0, 11.0 and 12.0 , by $\mathrm{HCl}\left(1 \mathrm{~mol} \mathrm{~L}^{-1}\right)$ or $\mathrm{NaOH}\left(1 \mathrm{~mol} \mathrm{~L}^{-1}\right)$. The solution was kept at $4^{\circ} \mathrm{C}$ for $24 \mathrm{~h}$. Afterwards, the samples were readjusted to $\mathrm{pH} 7.0$.

Protease tolerance: Equal sample volumes were treated with $1 \mathrm{mg} \mathrm{mL} \mathrm{m}^{-1}$ protease $\mathrm{K}$, papain, pepsin, trypsin and alkaline protease, at $37^{\circ} \mathrm{C}$ for $1 \mathrm{~h}$, and then kept in a water bath at $100^{\circ} \mathrm{C}$ for $5 \mathrm{~min}$ to inactivate the protease.

Ultraviolet radiation tolerance: Equal sample volumes were placed under $28 \mathrm{~W}$ ultraviolet radiation at $10 \mathrm{~cm}$, and were irradiated for $0.25 \mathrm{~h}, 0.5 \mathrm{~h}, 0.75 \mathrm{~h}, 1 \mathrm{~h}, 2 \mathrm{~h}, 4 \mathrm{~h}, 6 \mathrm{~h}$ and $12 \mathrm{~h}$. A sample of untreated antifungal protein of the same concentration was used as control. The experiment was conducted twice, and three independent replicates were conducted for each treatment.

The activity of the antifungal protein against $M$. oryzae was assessed based on the experiments described above.

\section{Effect of the antifungal protein treatment on mycelial morphology}

To assess the effect of the YN917 antifungal protein on the mycelial morphology of $M$. oryzae, $1 \mathrm{mg} \mathrm{mL}^{-1}$ of protein was added to a $250 \mathrm{~mL}$ Erlenmeyer flask filled with 50 $\mathrm{mL}$ of fresh PDB medium containing $M$. oryzae. The flask was kept at $28^{\circ} \mathrm{C}$ and shaken at $180 \mathrm{r} \mathrm{min}^{-1}$; it was then observed by microscope ( $\times 40$ magnification) after $1 \mathrm{~d}, 2 \mathrm{~d}, 3 \mathrm{~d}, 4 \mathrm{~d}$ and $5 \mathrm{~d}$. All assays were conducted in triplicate, and an intact mycelium showing normal growth with an equal volume of dd $-\mathrm{H}_{2} \mathrm{O}$ addition served as negative control.

\section{Effect of the antifungal protein on spore germination}

M. oryzae spores were mixed with the YN917 antifungal protein in a ratio of $1: 1(\mathrm{v} / \mathrm{v})$, sterile distilled water was used as negative control. The treatments were placed at $28^{\circ} \mathrm{C}$, and spore germination was observed by microscope $(\times 40$ magnification) after $2 \mathrm{~h}, 4 \mathrm{~h}, 6 \mathrm{~h}, 8 \mathrm{~h}, 10 \mathrm{~h}$ and $12 \mathrm{~h}$. One hundred single conidia per dish were examined, the experiment was duplicated, and three independent replicates were conducted for each treatment.

\section{In vitro control effect of the YN917 antifungal protein on M. oryzae}

Control of rice blast $M$. oryzae was evaluated by in vitro inoculation performed on rice leaves (Shi et al. 2015). In brief, same-sized healthy leaves were selected for testing at the 5-leaf stage. For the preventive treatment, the surface of the leaves was sprayed with $100 \mu \mathrm{g} \mathrm{mL} \mathrm{m}^{-1}$ of YN917 antifungal protein first, and after $24 \mathrm{~h}$ a $M$. oryzae spore suspension was inoculated. For the curative treatment, leaf surfaces were sprayed with $100 \mu \mathrm{g} \mathrm{mL}^{-1}$ of antifungal protein $24 \mathrm{~h}$ after being inoculated with the spore suspension. Negative controls were treated the same way using sterile distilled water, and the positive controls were treated with a 500 times diluent of $40 \%$ isoprothiolane $\mathrm{EC}$, and a 750 times diluent of $20 \%$ tricyclazole WP, in both the preventive and curative assays. All experiments were carried out in triplicate. The samples were placed at conditions of $85-100 \%$ relative humidity and temperature of $28^{\circ} \mathrm{C}$, with a $12 \mathrm{~h}$ photoperiod for $7 \mathrm{~d}$. They were moisturized regularly with water to maintain hydration, and the antagonistic effect was analyzed.

\section{Statistical Analysis}

The data were analyzed in S.P.S.S. 20.0 and were subjected to Duncan's analysis of variance; the means were separated by Duncan's multiple range tests at $P \leq 0.05$.

\section{Results}

\section{Optimum saturation of ammonium sulfate precipitation}

Different proteins have different saturation characteristics when they are precipitated by $\left(\mathrm{NH}_{4}\right)_{2} \mathrm{SO}_{4}$. Therefore, the specific optimum $\left(\mathrm{NH}_{4}\right)_{2} \mathrm{SO}_{4}$ precipitation saturation of the YN917 protein was investigated in this study. The results (Fig. 1) showed that the protein precipitated $\left(\mathrm{NH}_{4}\right)_{2} \mathrm{SO}_{4}$ at 20-30\% saturation had no inhibition on rice blast fungus, M. oryzae. When precipitated by $\left(\mathrm{NH}_{4}\right)_{2} \mathrm{SO}_{4}$ at $40 \%$ saturation, a slight inhibition on $\mathrm{M}$. oryzae was observed. When precipitated by $\left(\mathrm{NH}_{4}\right)_{2} \mathrm{SO}_{4}$ at $60 \%$ saturation, the protein increased considerably, and the inhibition was significantly enhanced. The protein precipitated by $\left(\mathrm{NH}_{4}\right)_{2} \mathrm{SO}_{4}$ at $80 \%$ saturation showed a stronger antifungal activity than at other saturation levels, while the inhibition effect declined when the saturation was more than $80 \%$. The results indicate that the optimum saturation of the precipitated antifungal crude protein from strain YN917 was $80 \%$.

\section{Antagonistic spectrum}

The antagonistic test using common plant pathogens and oomycetes showed that the antifungal protein had a broadspectrum antagonistic activity against the pathogens chosen for this research (Table 1). The maximum inhibition in the radial growth caused by the antifungal protein was $51.67 \%$ $\pm 1.73 \%$ for grape gray-mold fungus $B$. cinerea, $46.10 \% \pm$ $3.22 \%$ for strawberry gray-mold fungus $B$. cinerea, $42.86 \%$ 
Table 1: Antagonistic effects of B. cereus YN917 antifungal crude protein against fungal pathogens

\begin{tabular}{llll}
\hline Item & Host & Pathogen & Inhibition (\%) \\
\hline 1 & Grape & Botrytis cinerea & $51.67 \pm 1.73$ \\
2 & Strawberry & B. cinerea & $46.10 \pm 3.22$ \\
3 & Maize & Bipolaris maydis & $42.86 \pm 1.35$ \\
4 & Rice & Magnaporthe oryzae & $39.97 \pm 1.23$ \\
5 & Rice & Ustilaginoidea virens & $39.25 \pm 0.43$ \\
6 & Wheat & Fusarium graminearum & $38.82 \pm 2.04$ \\
7 & Tobacco & Phytophtora parasitica var. nicotianae & $38.02 \pm 2.19$ \\
8 & Potato & Alternaria solani & $32.63 \pm 1.15$ \\
9 & Rice & Rhizoctonia solan & $31.94 \pm 0.09$ \\
10 & Cotton & Verticillium dahliae & $30.26 \pm 1.12$ \\
11 & Tobacco & A. alternata & $29.14 \pm 3.94$ \\
12 & Orange & Diaporthe Citri & $28.70 \pm 1.23$ \\
13 & Spicy & F. oxysporum & $24.58 \pm 0.84$ \\
14 & Camphor & Colletotrichum gloeosporioides & $22.97 \pm 0.51$ \\
15 & Rape & Sclerotinia sclerotiorum & $22.48 \pm 1.43$ \\
\hline \multicolumn{7}{l}{ Mean } & standard deviation
\end{tabular}

$\pm 1.35 \%$ for southern corn-leaf blight fungus B. maydis and $39.97 \% \pm 1.23 \%$ for rice blast fungus $M$. oryzae. When compared with the controls, each of the treatments showed a significant difference $(P \leq 0.05)$ suggesting this protein has a potential to be successfully used in disease prevention.

\section{Physicochemical properties}

Temperature tolerance: To examine thermo-stability, the antifungal crude protein was placed at different temperatures for $1 \mathrm{~h}$ and antifungal activity was determined. The results (Fig. 2) showed that the inhibition rate on $M$. oryzae changed significantly after being exposed to different temperatures $(P \leq 0.05)$. The antifungal activity was stable after exposure to temperatures between $-20^{\circ} \mathrm{C}$ and $40^{\circ} \mathrm{C}$. When the temperature was higher than $40^{\circ} \mathrm{C}$, the inhibition rate and associated antifungal activity was significantly decreased. After exposure to $70-121^{\circ} \mathrm{C}$, the inhibition rate continued to decrease significantly. This indicated that the crude antifungal protein has thermostability, and it can function adequately in the natural environment, showing a significant potential for its development and application.

pH tolerance: To assess $\mathrm{pH}$ stability, the antifungal protein was incubated at different $\mathrm{pH}$ values for $24 \mathrm{~h}$ and antifungal activity was determined. The results (Fig. 3) showed that the inhibition rate on $M$. oryzae changed significantly after different $\mathrm{pH}$ treatments $(P \leq 0.05)$. The inhibition rate of the YN917 antifungal protein was stable at $\mathrm{pH}$ values between 5.0 and 8.0, and the inhibitory activity sharply decreased at $\mathrm{pH}$ values $<5.0$ or $\mathrm{pH}$ values $>8$, which indicated that the protein is sensitive to overly acidic or overly alkaline conditions, but it maintains a sufficient antifungal activity against $M$. oryzae when $\mathrm{pH}$ is between 5.0 and 8.0.

Protease tolerance: Compared with the control, the inhibition rate of the antifungal protein did not change during protease treatments. However, when comparing protease treatments, the protein was more sensitive to protease $\mathrm{K}$, alkaline protease, trypsin, pepsin and papain, and its antifungal activity was weakened after these

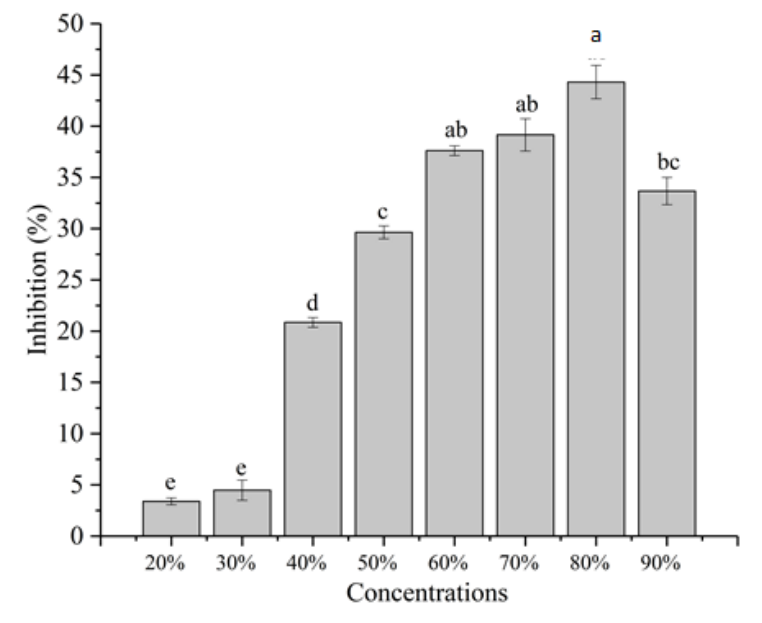

Fig. 1: Inhibitory results with different ammonium sulfate saturation

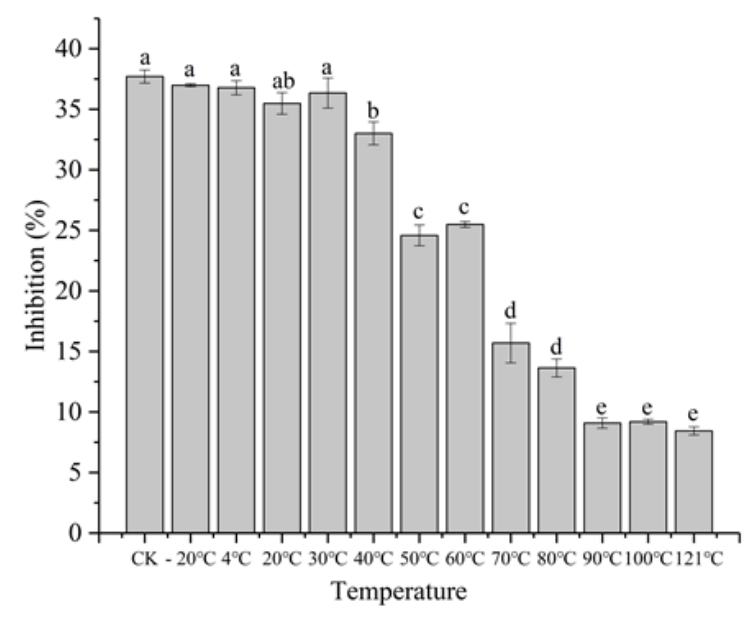

Fig. 2: Stability of YN917 antifungal protein at different temperatures

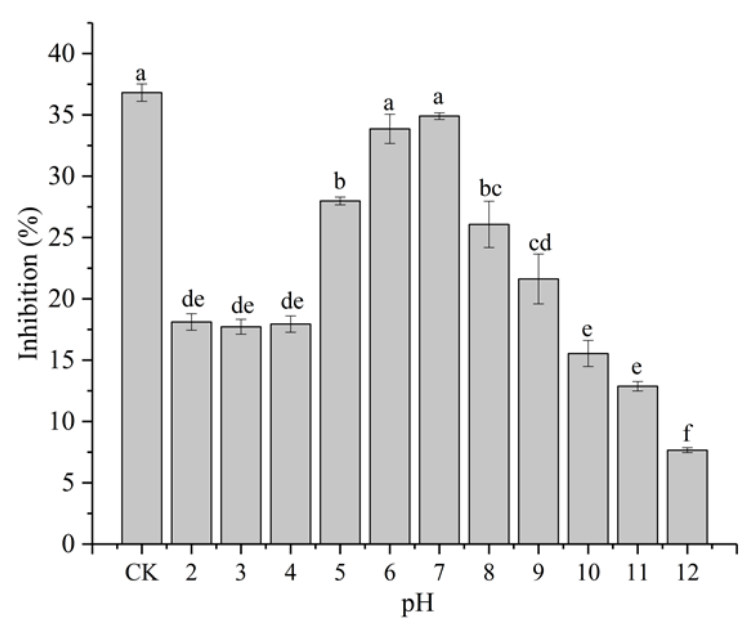

Fig. 3: Stability of YN917 antifungal protein at different $\mathrm{pH}$ values

treatments (Fig. 4). It was particularly sensitive to trypsin and pepsin, which indicated that the antifungal protein can be digested by proteases in the human digestive system and 


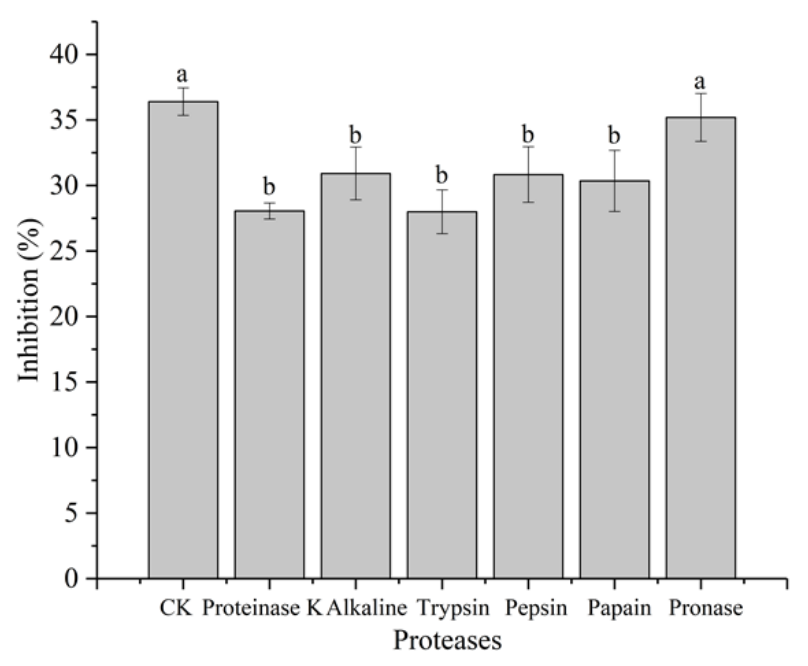

Fig. 4: Stability of YN917 antifungal protein in the presence of proteases

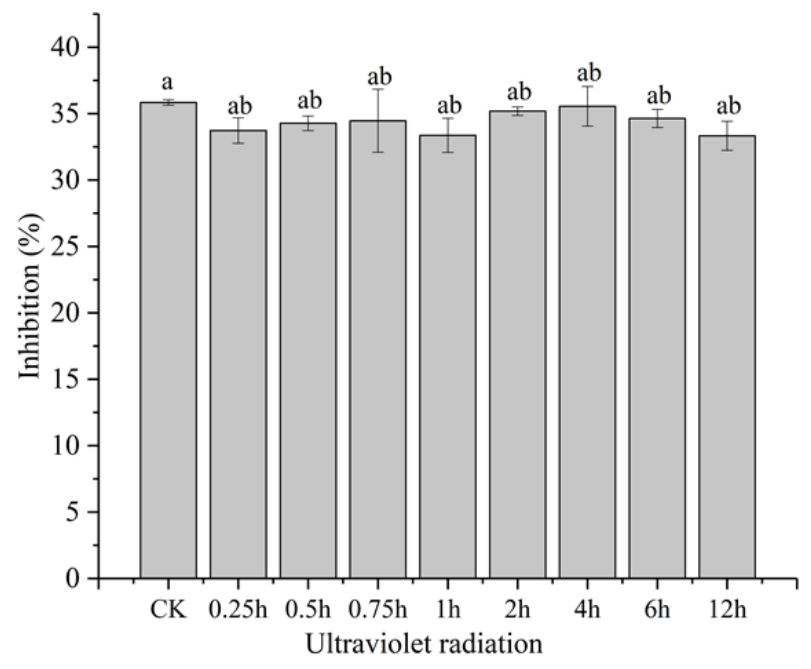

Fig. 5: Stability of YN917 antifungal protein exposed to ultraviolet radiation

it will not adversely affect human health. Therefore, this protein can be safely used in the biological control of crops.

Ultraviolet radiation tolerance: To assess UV stability, the antifungal protein was irradiated by ultraviolet radiation for $0.25-12 \mathrm{~h}$ and antifungal activity was determined. The activity remained stable (Fig. 5), which indicated that the protein is not sensitive to ultraviolet radiation and has good anti-ultraviolet properties.

\section{Effect of the YN917 protein on M. oryzae spores}

Spore production and germination of $M$. oryzae were determined in the presence of YN917. The results obtained showed the protein preparation had a significant potent inhibitory effect on the fungal spore production of $M$. oryzae at varied times. Distilled water, used as negative control, did not inhibit spore production (Fig. 6 and Table 2). Moreover, the spores treated with the protein exhibited a swollen shape, while non-treated spores maintained their normal morphology. This suggests that the antifungal protein has a strong inhibitory effect on the spore germination of $M$. oryzae, affecting also the permeability of the conidiospore membranes.

\section{Effect of the YN917 protein on M. oryzae mycelium}

To assess the strength of the protein's antifungal effect, the mycelium of $M$. oryzae was microscopically observed near the zone where inhibition occurred, (Fig. 7) which revealed signs of extensive lysis of the spores; in particular abnormal distortion, slender shapes, multiple swelling and spore disintegration were observed. In contrast, the untreated negative control presented a normal mycelium and smooth surfaces. This suggests that the YN917 antifungal protein is effective in inhibiting spore formation and germination.

\section{In vitro control effect of the YN917 antifungal protein}

In order to evaluate the antifungal activity of $B$. cereus YN917 against $M$. oryzae, in vitro experiments were carried out on infected rice leaves of the rice cultivars 'Yuzhenxiang', 'Y-liangyou1998' and 'Xiangwanxian No.12'.' The efficacy of biocontrol in the separate leaf assays is shown in Table 3 . In both the preventive and curative treatments, the YN917 antifungal protein showed a significant bio-control efficacy against $M$. oryzae. In the prevention treatment, leaves treated with the protein had a lower incidence rate of disease (18.4\% in Yuzhenxiang, $19.63 \%$ in Yliangyou 1998 and 14.26\% in Xiangwanxian No 12) and presented smaller lesions than leaves without any treatment $(97.26 \%$ in Yuzhenxiang, $97.66 \%$ in Yliangyou 1998 and $98.33 \%$ in Xiangwanxian No 12). In the curative treatment, the disease indexes of the protein were $22.53,25.31$ and $24.51 \%$, respectively. The results were similar in both the preventive and curative samples, indicating that the YN917 antifungal protein may be effective as a potential bio-control agent against rice blast.

\section{Discussion}

This study is the first detailed investigation of the effects of temperature, $\mathrm{pH}$ value, ultraviolet radiation, and protease on the stability of the YN917 antifungal protein. The results describe the most favorable environmental conditions in which the protein remains active, which is particularly relevant for predicting bio-control responses. Overall, the protein can withstand a wide range of stress conditions. Stress tolerance is an important index to evaluate the applicability of a bio-control strain, based on the stability of the physical and chemical properties of its antifungal substances. Thermostability and $\mathrm{pH}$-stability play a key role in the production and application of antifungal proteins. In 
Table 2: Effect of YN917 antifungal protein on M. oryzae spore germination

\begin{tabular}{llllll}
\hline Treatment & $2 \mathrm{~h}$ & $4 \mathrm{~h}$ & $6 \mathrm{~h}$ & $8 \mathrm{~h}$ & $10 \mathrm{~h}$ \\
\hline CK & $7.69 \pm 1.49$ & $34.48 \pm 3.46$ & $55.26 \pm 2.61$ & $74.45 \pm 2.32$ & $88.19 \pm 2.55$ \\
YN917 protein & $1.96 \pm 0.64$ & $4.00 \pm 1.03$ & $13.16 \pm 1.83$ & $12.30 \pm 2.31$ & $24.16 \pm 3.07$ \\
\hline
\end{tabular}

Table 3: Effect of YN917 antifungal protein on rice blast control in vitro

\begin{tabular}{|c|c|c|c|c|c|c|}
\hline \multirow[t]{2}{*}{ Treatments } & \multicolumn{2}{|c|}{ Yuzhenxiang } & \multicolumn{2}{|c|}{ Y-liangyou1998 } & \multicolumn{2}{|c|}{ Xiangwanxian No.12 } \\
\hline & $-24 \mathrm{~h}$ & $+24 \mathrm{~h}$ & $-24 \mathrm{~h}$ & $+24 \mathrm{~h}$ & $-24 \mathrm{~h}$ & $+24 \mathrm{~h}$ \\
\hline$\overline{\mathrm{CK}}$ & $97.26 \pm 2.48 \mathrm{a}$ & $92.41 \pm 3.66 \mathrm{a}$ & $97.66 \pm 1.66 \mathrm{a}$ & $94.75 \pm 1.67 \mathrm{a}$ & $98.33 \pm 2.36 \mathrm{a}$ & $98.30 \pm 0.42 \mathrm{a}$ \\
\hline $25 \%$ Tricyclazole WP & $7.36 \pm 0.55 \mathrm{c}$ & $54.46 \pm 2.29 \mathrm{~b}$ & $10.67 \pm 0.94 \mathrm{c}$ & $52.96 \pm 2.28 b$ & $9.00 \pm 0.82 \mathrm{~d}$ & $56.11 \pm 2.83 b$ \\
\hline $100 \mathrm{ug} / \mathrm{mL}$ protein & $18.40 \pm 1.36 \mathrm{~b}$ & $22.53 \pm 4.16 \mathrm{c}$ & $19.63 \pm 2.29 b$ & $25.31 \pm 1.43 \mathrm{c}$ & $14.26 \pm 2.33 \mathrm{c}$ & $24.51 \pm 2.00 \mathrm{c}$ \\
\hline
\end{tabular}

Mean \pm standard deviation. Values sharing same letters do not significantly differ $(P>0.05)$

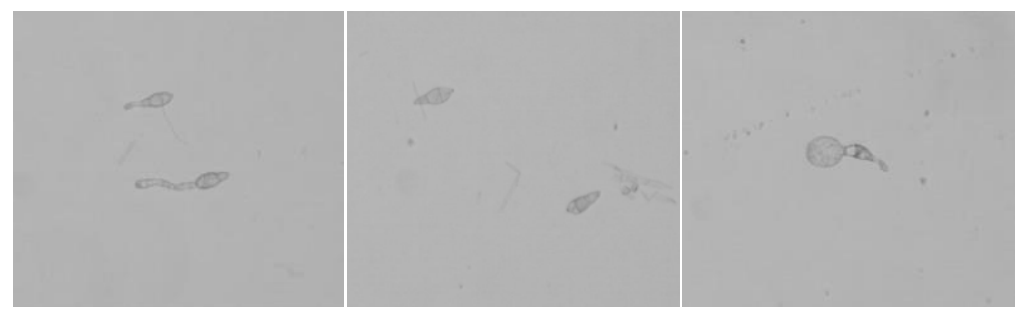

Fig. 6: Effect of the YN917 antifungal protein on M. oryzae spores

(A) Normal spores (CK); (B), (C) abnormal spores of M. oryzae appear bulbous and swollen

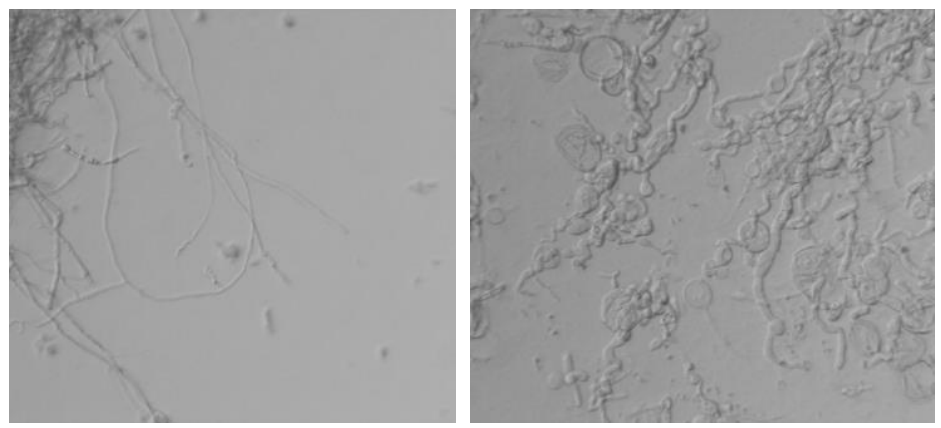

Fig. 7: Effect of the YN917 antifungal protein on M. oryzae mycelium

A negative control, without YN917 protein treatment showing normal mycelium morphology and spore germination; B mycelium treated with YN917 protein showing extensive

lysis of the mycelia and destructed spores

particular it is important that antifungal proteins maintain a high antifungal activity at $\mathrm{pH}$ values between 8.0 and 11.0 and at temperatures below $70^{\circ} \mathrm{C}$, conditions which better suit industrial production prospects (Oberoi et al. 2001).

In relation to the present study specifically, the results have confirmed that the YN917 protein has a wide temperature adaptation range, and can maintain a high antifungal activity after being exposed to $80^{\circ} \mathrm{C}$ for $30 \mathrm{~min}$. This protein is considerably adapted to withstand high temperatures, providing an advantage when used in cultivation crops (specifically in the summertime). In addition, it is not sensitive to ultraviolet radiation, but acidic $\mathrm{pH}$ values in in vitro experiments seemed to significantly restrict its activity. The suitable soil $\mathrm{pH}$ value ensuring antifungal activity was between 5.0 and 8.0, which does correspond to the natural growth ring of common crops. Moreover, the protein is sensitive to trypsin and pepsin treatment, which indicates that it can be digested by protease in the human digestive system and is therefore harmless to human health. In summary, this study has shown that from an ecological point of view, the YN917 protein has a wide tolerance to various stressors such as temperature, $\mathrm{pH}$, ultraviolet radiation, and protease, which suggests that it could be applied to a wide range of environmental conditions.

Many antifungal proteins derived from Bacillus spp. have a strong inhibition activity (Gotor-Vila et al. 2017). For example, the antifungal protein derived from $B$. subtilis ZL2-70 was shown to strongly inhibit $V$. dahliae, Fusariumum graminearum, C. gloeosporioides, and 19 other plant pathogens; the Bacisubin protein isolated from $B$. subtilis B-916 can inhibit the growth of various pathogens such as $M$. oryzae, $B$. cinerea, and $A$. brassicae (Luo et al. 2009). The antifungal protein YN917 derived from the B. cereus YN917 strain presents a broad antifungal spectrum, which can effectively inhibit the mycelial growth 
of 15 pathogenic fungi and oomycetes, such as M. oryzae, $B$. cinerea and B. maydis. The experiments carried out in this particular study showed that this antifungal protein has a strong inhibitory effect on the growth and germination of $M$. oryzae spores. Furthermore, several antifungal proteins have been shown to inhibit fungal mycelium and the germination of spores (Leelasuphakul et al. 2008; Matar et al. 2009). For example, a novel protein produced by $B$. subtilis B29 (Li et al. 2009), can inhibit the conidial spore germination of $F$. oxysporum, suppress germ-tube elongation, and induce distortion, tumescence and rupture of a portion of the germinated spores. The Bacisubin protein, produced by B. subtilis B-916 (Liu et al. 2007) can cause the $R$. solani mycelia to enlarge and rupture, and the crude antifungal protein RY3 produced by $B$. amyloliquefacens RY3 can inhibit the germination of $P$. digitatum spores (Chen et al. 2013). Finally, the protein produced by $B$. cereus HS24, can significantly inhibit conidium germination and mycelial growth in M. oryzae (Huang et al. 2019).

There is an urgent need for more efficient and sustainable alternatives to chemical fungicides to prevent or control diseases and reduce food production losses (Mnif et al. 2015). In this article, we have confirmed the B. cereus derived YN917 protein is a potent antifungal agent against $M$. oryzae. The results showed that its antifungal activity against rice blast fungus $M$. oryzae in vitro was like that of $25 \%$ tricyclazole WP and $40 \%$ isoprothiolane EC, suggesting that this protein can be a potential natural fungicide alternative to be used to effectively prevent or control rice blast in crop cultivations.

Bacillus spp. in nature can produce different secondary metabolites, which are related to microorganisms in different ecological environments. These secondary metabolites include antifungal and antiseptic substances, biofertilizers, as well as various active enzymes. Therefore, the determination of the antifungal components produced by the YN917 protein will be the objective of our future research.

\section{Conclusion}

In the present work, results indicate that there are natural antifungal substances in the YN917 strain of B. cereus. The YN917 protein showed a broad-spectrum antagonistic activity against 15 plant pathogens. Its physical and chemical properties were relatively stable and had a dual inhibitory effect on mycelium growth and conidiospore germination in $M$. oryzae. In vitro experiments revealed that its control effect against rice blast was considerable. Therefore, protein extracts from the YN917 strain can be considered as a promising and novel bio-control resource to be used in agricultural production.

\section{Acknowledgements}

This work was funded by the National Key R\&D Program of China (2016YFD0300700), central government financed projects, China (2014ZX0800102B) and the Public welfare industry (agriculture) special scientific research projects, China (201203014).

\section{Author Contributions}

Conceptualization, HZ; Methodology, HZ; Validation, HZ, HZ, LH, XY; Formal Analysis, HZ and HZ; Data Curation, HZ; Writing-Original HZ; Writing-Review and Editing, HZ and EL; Supervision, ZR; Funding Acquisition, ZR and EL

\section{Conflict of Interest}

The authors declare that they have no conflict of interest.

\section{Data Availability}

All data will be available upon reasonable request to the corresponding author.

\section{Ethics Approval}

Not applicable.

\section{References}

Ali A, A Javaid, A Shoaib, IH Khan (2020). Effect of soil amendment with Chenopodium album dry biomass and two Trichoderma species on growth of chickpea var. Noor 2009 in Sclerotium rolfsii contaminated soil. Egypt J Biol Pest Cont 30:102-110

Al-Reza SM, A Rahman, Y Ahmed, SC Kang (2010). Inhibition of plant pathogens in vitro and in vivo with essential oil and organic extracts of Cestrum nocturnum L. Pestic Biochem Physiol 96:86-92

Arpita B, PG Ved, PS Satyendra, P Shipra, C Priyanka, KS Sumit, S Suchi, CS Poonam, M Aradhana (2019). Intervention of bio-protective endophyte Bacillus tequilensis enhance physiological strength of tomato during Fusarium wilt infection. Biol Cont 139; Article 104074

Bodhankar S, M Grover, S Hemanth, G Reddy, S Rasul, SK Yadav, S Desai, M Mallappa, M Mandapaka, C Srinivasarao (2017). Maize seed endophytic bacteria: Dominance of antagonistic, lytic enzymeproducing Bacillus spp. Biotechnology 7:1-13

Chen ZL, H Zhang, NN Zhang, YJ Qiao (2013). Physicochemical property and inhibitory activity against Pennicillium digitatum of antifungal crude protein produced by Bacillus amyloliquefacens RY3. Food Mach 29:187-190

Dorighello DV, W Bettiol, NB Maia, MVBCL Regina (2015). Controlling Asian soybean rust (Phakopsora pachyrhizi) with Bacillus spp. and coffee oil. Crop Prot 67:59-65

DowdPF,FEVega, TCNelsen, JL Richard (1998). Dusky sap beetle mediated dispersal of Bacillus subtilis to inhibit Aspergillus flavus and aflatoxin production in maize Zea mays L. Biocont Sci Technol 8:221-235

Etesami H, HA Alikhani, HM Hosseini (2019). Root bacterial endophytes as potential biological control agents against fungal rice pathogens. Arch Phytopathol Pflanzensch 52:560-581

Gotor-Vila A, N Teixidó, M Sisquella, R Torres, J Usall (2017). Biological characterization of the biocontrol agent Bacillus amyloliquefaciens CPA-8: The effect of temperature, $\mathrm{pH}$ and water activity on growth, susceptibility to antibiotics and detection of enterotoxic genes. Curr Microbiol 74:1089-1099

Hammami I, MA Triki, A Rebai (2011). Purification and characterization of the novel bacteriocin Back IH7 with antifungal and antibacterial properties. J Plant Pathol 93:443-454 
He Y, M Zhu, J Huang, T Hsiang, L Zheng (2019). Biocontrol potential of a Bacillus subtilis strain BJ-1 against the rice blast fungus magnaporthe oryzae. Can J Plant Pathol 41:47-59

Huang WX, XY Liu, XS Zhou, XL Wang, XY Liu, HX Liu (2019). Calcium signaling is suppressed in magnaporthe oryzae conidia by bacillus cereus HS24. Phytopathology 110:309-316

Javaid A, F Anjum, N Akhtar (2019). Molecular characterization of Pyricularia oryzae and its management by stem extract of Tribulus terrestris. Intl J Agric Biol 21:1256-1262

Johansson AH, S Bejai, A Niazi, S Manzoor, E Bongcam-Rudloff, J Meijer (2014). Studies of plant colonisation by closely related Bacillus amyloliquefaciens biocontrol agents using strain specific quantitative PCR assays. Anton Leeuwen 106:1247-1257

Kimura N, A Fukuchi (2018). Mbi-d resistance management of pyricularia oryzae using an application program incorporating benomyl. J Pestic Sci 43:33-35

Kong QJ, X Yu, DD Song, XY Ren (2018). Effect of tricyclazole on morphology, virulence and gene expression of Aspergillus aculeatus for management of soft rot disease in peach. $J$ Appl Microbiol 125:1827-1835

Kusajima M, M Inoue, M Fujita, K Miyagawa, R Horita, H Nakashita (2018). Activation of cell proliferation in Arabidopsis root meristem by isoprothiolane. J Pestic Sci 43:261-265

Leelasuphakul W, P Hemmanee, S Chuenchitt (2008). Growth inhibitory properties of Bacillus subtilis strains and their metabolites against the green mold pathogen (Penicillium digitatum Sacc.) of citrus fruit. Postharv Biol Technol 48:113-121

Li J, Q Yang, LH Zhao, SM Zhang, YX Wang, XY Zhao (2009). Purification and characterization of a novel antifungal protein from Bacillus subtilis strain B29. J Zhej Univ Sci B 10:264-272

Liu X, Y Fang, F Xie, RR Zhang, HY Huang (2017). Synthesis and in vivo fungicidal activity of some new quinoline derivatives against rice blast. Pest Manage Sci 73:1900-1907

Liu Y, Z Chen, TB Ng, J Zhang, M Zhou, F Song, F Lu, Y Liu (2007). Bacisubin, an antifungal protein with ribonuclease and hemagglutinating activities from Bacillus subtilis strain B-916. Peptides 28:553-559
Luo C, Z Chen, Y Liu, J Zhang, Y Nie (2009). Construction and function analysis of Bac operon mutants of bio-control strain Bacillus subtilis Bs-916. Acta Microbiol Sin 49:445-452

Matar SM, SA El-Kazzaz, EE Wagih, AI El-Diwany, EE Hafez (2009). Antagonistic and inhibitory effect of Bacillus subtilis against certain plant pathogenic fungi, I. Biotechnology 8:53-61

Mnif I, I Hammami, MA Triki, MC Azabou, S Ellouze-Chaabouni, D Ghribi (2015). Antifungal efficiency of a lipopeptide biosurfactant derived from Bacillus subtilis SPB1 versus the phytopathogenic fungus, Fusarium solani. Environ Sci Pollut Res 22:18137-18147

Oberoi R, QK Beg, S Puri, RK Saxena, R Gupta (2001). Characterization and wash performance analysis of an SDS-stable alkaline protease from a Bacillus spp. World J Microbiol Biotechnol 17:493-497

Ongena M, P Jacques (2008). Bacillus lipopeptides: Versatile weapons for plant disease biocontrol. Trends Microbiol 16:115-125

Ryder M, R Warren, P Harvey, W Tang, H Yang, X Zhang (2005). Recent advances in biological control of soil borne root diseases of wheat, vegetables and cotton in China and Australia. Shand Sci 18:1-8

Sharf W, A Javaid, A Shoaib, IH Khan (2021). Induction of resistance in chili against Sclerotium rolfsii by plant growth promoting rhizobacteria and Anagallis arvensis. Egypt J Biol Pest Cont 31:16-25

Shi BH, H Zheng, JZ Huang, XL Luo, XZ Luo (2015). Purification and partial characterization of a thermostable antimicrobial protein from Bacillus subtilis FB123. World J Microbiol Biotechnol 31:1285-1290

Shoaib A, H Ali, A Javaid, ZA Awan (2020). Contending charcoal rot disease of mungbean by employing biocontrol Ochrobactrum ciceri and zinc. Physiol Mol Biol Plants 26:1385-1397

Stadnik A, A Borzecki (2009). Influence of the zearalenone on the activity of chosen liver enzymes in a rat. Ann Agric Environ Med 16:31-35

Wu L, W Xiao, G Chen, D Song, MA Khaskheli, P Li, S Zhang, G Feng (2018). Identification of Pseudomonas mosselii BS011 gene clusters required for suppression of rice blast fungus Magnaporthe oryzae. $J$ Biotechnol 16:1-9

Zhang XJ, T Hong, HL Li, J Wang (1994). Inhibition of Maifengning B3 (Bacillus spp., a biological fungicide) to wheat sharp eyespot (Rhizoctonia cerealis). Acta Phytopathol Sin 24:361-366 